\title{
Of Several Monetary Variables on Economic Growth and Its Implications on FDI (Studies Analysis in Indonesia and Malaysia)
}

\author{
Zainal Arifin H. Masri ${ }^{1}$, Cicih Ratnasih ${ }^{2}$, Yolanda ${ }^{3}$ \\ \{zarifin243@yahoo.com¹, cicih_ratnasih@borobudur.ac.id², yolanda@borobudur.ac.id ${ }^{3}$ \} \\ Universitas Borobudur, Jakarta, Indonesia ${ }^{1,2,3}$
}

\begin{abstract}
This study analyzes the effect of the money supply, interest rate, inflation, public saving and exchange rate variables on economic growth and their implications for FDI, in Indonesia and Malaysia. The data used is secondary data during the period 1980-2019. This research uses multiple linear regression model of data in a time series. The findings revealed that the monetary factors had a considerable impact on economic development and foreign direct investment in both countries. Interest rates, inflation, and exchange rates all had a substantial impact on Indonesia's economic growth. In the meanwhile, the currency rate is important for FDI. Which have a huge impact on economic growth in Malaysia are interest and inflation, on FDI are economic growth and inflation.
\end{abstract}

Keywords: Monetary Variables; Indonesia; Malaysia; Time Series; Linear Regression Multiple

\section{Introduction}

\subsection{Background}

The COVID-19 pandemic has devastated the economy of almost all countries. The economic growth of many countries in 2020 experienced contraction (negative economic growth) resulting in an economic recession. The most popular definition of an economic recession that is still used today is that of the US economist Julius Shiskin. Shiskin in an article entitled "The Changing Business Cycle" published in the New York Times in 1974, said A recession is defined as a two-quarter drop in real gross national product (GNP). An economic recession can also occur when real economic growth for two or more quarters of a year is negative. The Indonesia and Malaysia's economies are expected to grow at a similar rate in 2020 contraction as shown in table 1.

Table 1. Economic growth of Indonesia and Malaysia in 2020

\begin{tabular}{cccccc}
\hline \multirow{2}{*}{ No } & Country & \multicolumn{4}{c}{ Year 2020 } \\
\cline { 3 - 6 } & & Quarter 1 & Quarter 2 & Quarter 3 & Quarter 4 \\
\hline 1 & Indonesia & $2,97 \%$ & $-5,32 \%$ & $-3,49 \%$ & $-2.19 \%$ \\
2 & Malaysia & $-0,7 \%$ & $-17,1 \%$ & $-2,7 \%$ & $-3,4 \%$ \\
\hline \multicolumn{4}{c}{ Source: $w w w$} \\
\hline
\end{tabular}


Indonesia has only experienced an economic recession starting in the 2nd quarter, while Malaysia has already experienced an economic recession in the 1 st quarter of 2020. An economic recession if it occurs for a long time is called an economic depression. Depression is a drastic and sustainable economic downturn in the long term. To overcome the economic recession so that it does not spread into an economic depression and all its impacts, the government carries out economic policies that are expected to be able to control and restore economic stability. The types of economic policies carried out by the government according to Mathias Aroef can be grouped into 3 groups, namely: Supply-side policy, fiscal policy, and monetary policy [1].

a. Fiscal policy is the process of the government modifying its policies state revenues and state expenditures/expenditures with the aim of controlling the economy for the better. Examples of fiscal policies include increasing tax revenues and types of taxes, requiring the ownership of a TIN, saving state expenditures, making loans/debts by issuing state debt securities and foreign debt.Monetary policy is the policy of the monetary authority or the The goal of the Central Bank is to keep the money supply under control in society to achieve certain goals, for example controlling inflation, maintaining the stability of the rupiah exchange rate, and increasing employment opportunities, determining The money supply and interest rates.

b. Supply-side policy is a government policy in the economic field to increase the efficiency of companies so that they can increase the supply of goods and services with lower prices and better quality.

c. Monetary policy variables include: money supply or money supply, interest, inflation, saving, rate of change. The monetary policy variable is used to measure how well a country's monetary policy is working see the effect of the monetary policy variable on economic growth and its implications for foreign investment inflows (FDI).

The money supply, sometimes known as the money supply, has a significant impact on the economy. Economic growth may be harmed as a result of the adjustments. Irving Fisher's quantity theory of money asserts that the money supply multiplied by the velocity of circulation equals the price in his book "The Purchasing Power of Money Its Determination and Relation to Credit Interest and Crisis multiplied by the aggregate output. (M X V $=\mathrm{PX}$ T, where $\mathrm{M}=$ money supply, $\mathrm{V}=$ velocity of money supply which is constant in quantity, $\mathrm{P}=$ price and $\mathrm{T}=$ quantity of goods). The money supply, sometimes known as the money supply, has a favorable impact on economic growth. The more the money supply increases, the more economic growth increases and vice versa.

Economic growth will affect investors to invest in a country. Positive economic growth will stimulate foreign investors to invest. Interest rates are determined by the supply and demand for money in the money market, according to the theory of liquidity preference or Keynes' theory of interest rate determination in his book "The General Theory of Employment, Interest, and Money" (1936, 2017 reprint edition). The rate of interest determined by the bank has an influence on people's speculation to put their money in the bank. According to Frederick Hayek, a low interest rate not only causes high investment, but also causes "malinvestment". Too much investment in long-term projects over short-term projects turns into failure. (www.Nobellaureates.com) Low interest causes people to borrow money from banks. Some of the loans by the public are spent for consumption and some are used for business or business expansion so that economic growth increases.

High bank interest rates encourage people to prefer to save their money rather than use it for business or develop their business which causes the economy to become sluggish and economic growth to decline. According to Barro, Inflation is a rise in the cost of consumer 
products in general and continuously [2]. Meanwhile, Brown said that inflation cannot be said if the increase in the price of goods is only one or two goods, except when the increase in prices results in an increase in the price of other goods [3]. Meanwhile, Case argues that inflation is related to market mechanisms caused by various factors, including: high public consumption, the ability to pay or purchasing power that is so large in the market that encourages consumption or even speculation, including due to congestion in the distribution of goods [4]. According to Keynes, people's savings are not influenced by interest, but are influenced by people's income. The greater the the higher the level of income, the higher the level of savings.

The value of the exchange rate fluctuates, one time the exchange rate goes up while another the exchange rate goes down. This can be explained in the theory of purchasing power parity (Purchasing Power Parity). Gustav Cassell's law of one price underpins the purchasing power parity theory, which states that one unit of currency may buy the same amount of goods in all countries [5]. FDI In addition to having an impact on a country's economy, it also has a detrimental impact on the host country's economic development country. The positive impacts of FDI as mentioned above are additional development funds, transfer of knowledge and technology, and job creation. While the negative impact of FDI is the hegemony of foreign countries against the host country, and environmental damage caused by excessive natural exploration.

\subsection{Problem Identification}

Based on the above background, the following problems can be identified:

a. The money supply, interest rate, inflation, public savings, and exchange rate all play a role in economic growth. The money supply, interest rate, inflation, public saving, exchange rate and economic growth together have a significant effect on FDI

b. The money supply has a considerable impact on economic growth on its own.

c. Interest rates at the individual level have a substantial impact on economic growth.

d. Inflationary pressures on individuals have a considerable impact on economic growth.

e. Personal savings have a big impact on economic growth.

f. The exchange rate of each individual has a substantial impact on economic growth.

g. The money supply has a substantial impact on FDI on its own.

h. Individual interest rates have a large impact on FDI.

i. Inflationary pressures on individuals have a big impact on FDI.

j. Individual savings have a large impact on FDI.

$\mathrm{k}$. Individual exchange rates have a substantial impact on FDI.

1. Individual economic growth has a considerable impact on foreign direct investment.

\section{Literature Review}

\subsection{Monetary Policy}

\subsubsection{Definition of Monetary Policy}

Monetary policy is the the central bank's policy in the context of economic stability. Stable economic indicators include high economic growth, stability in prices of goods and services, equitable development, balance of payments balance, job opportunities and others. Monetary 
policy is carried out by regulating the money supply, interest rates, inflation targeting, exchange rates and people's savings. Natsir said that monetary policy is an attempt by the central bank to influence the development of monetary variables (money supply, exchange rates, and interest rates)[6]. Meanwhile, Perry Warjiyo said that monetary policy is the the central bank's policy in the form of of monetary aggregates to achieve the development of economic activities carried out by taking into account the cycle of economic activity, the economic nature of a country and other fundamental economic factors [7].

\subsubsection{Multiple Monetary Variables}

Monetary variables are a small part of macroeconomic variables. In the economy, several macroeconomic variables that are often used to assess monetary policy are:

a. The first is the money supply. The money supply is the total amount of money in circulation in an economy, including currency, demand deposits, quasi money, bonds with maturities of less than 1 year. The money supply in the USA according to Anna J Schwartz consists of paper money, The Federal Reserve System and the US Treasury have created coins, as well as numerous sorts of deposits held by the public in commercial banks and other depository institutions [8].

b. The rate of interest. The interest rate, according to Pindyck, is is the price paid by the borrower to the lender [9].

c. Inflation. Samuelson defines inflation as an a rise in the cost of products, services, and production inputs [10].

d. Community savings. Community saving is part of income received by the community which has not been used for consumption icon or for future consumption. Community saving is the same as income reduced by community consumption. Savings only occurs if the income is greater than the consumption. which must be issued plus taxation which must be paid. The factors that determine community savings include, among others: community income, interest rates. The higher the level of trust the public has in bank

e. The rate of exchange. The exchange rate is defined as the difference in value between two currencies of one currency currency with another currency [11]. Factors that affect this value are: imports, capital outflow factors, speculative activities, revenues and exports, capital flows in (capital inflows).

\subsection{Economic Growth}

Todaro explained that the process of expanding production is known as economic growth capacity in an economy over time and is unable to generate an increase in national income [12]. Rapanna dkk mentions factors that influence economic growth, including: natural resources, human resources, investment, and technology [13]. There are several theories of economic development in various economics literatures [14][15][16] or as it is written in the article "Corporate Finance Institute", other.

\subsubsection{Classical Theory}

Developed since the 17 th century, with its famous characters, namely, Adam Smith, David Ricardo and Thomas Robert Malthus.

a. Theory Adam Smith. Adam Smith explained that there are two factors that influence economic growth, total output and population growth factors. The calculation of the total 
output using three variables, namely, natural resources, human resources, and modal resources. The area of the market and the rate of economic expansion are determined by population increase[17].

b. The David Ricardo theory. David Ricardo said that economic growth will only be achieved if the productivity of the workforce is supported by technological advances and a large amount of capital is accumulated[17].

c. Theory Thomas Robert Malthus. Malthus in his book "An Essay on the Principle of Population" published in 1798 said that the population growth rate is according to the geometrical series, while the growth rate of food is according to the arithmetic series. The growth in population is much greater than the growth in food, so there will be fish shortages[17].

\subsubsection{Neoclassical Theory}

There are three well-known figures in the theory of ineoclation [18]: namely HarodDomar, Joseph A Schumpeter and Robert Solow:

a. Harod-Domar theory of growth and economics. R.F. Harrod and Evsey Domar who introduced this theory. According to them, to achieve strong economic growth, it requires the formation of capital or investment.

b. Joseph A. Schumpeter's theory of economic growth. Joseph A. Schumpeter in his according the book "The Theory of Economic Development," economic growth is a form of innovation process that is carried out by innovators and entrepreneurs.

c. Robert Solow's theory of economic growth. Economic growth according to Robert Solow is a set of activities that are dependent on four primary factors: people, capital accumulation, modern technology, and the outcome (output).

\subsubsection{Historical Economic Growth Theory}

The economists who came up with this theory include:

a. Theory of economic growth Friedrih List. The list categorizes i4 stages of economic growth, i.e., i: hunting and wandering stage i (depending on nature), livestock raising and farming stage, farming and crafting stage, craft stage, industry and commerce

b. Theory of economic growth Werner Sombart. Sombart said that there are three stages of economic growth, namely: the closed economic stage/age, the craft-and-growth stage/age, and the capitalist stage/age.

c. Walt Whitman Rostow's theory of economic growth. W.W. Rostow in his book "The Stages of Economic, A Non-Communist Manifesto" growth economic growth and development theory. Rostow said that the economic growth of the society took place through stages, namely: the traditional society or traditional isociety, the preconditions for leaving the ground or the icon consumption

d. Bruno Hildebrand's theory of economic growth. According to Bruno, the stages of economic growth are the period of exchange for goods (barter), the period of exchange for money, the period of exchange for credit.

e. Theory of economic growth Karl Bucher. The stages of economic growth according to Karl Bucher are: the people are still subsistence, the barter economy (exchange of products), the international economy, the economy with trade that crosses the borders of a country. 


\subsubsection{Keynes Theory}

John Meynard Keynes explained his economic theory in his book, his essay entitled "Employment, Interest, and Money: A General Theory". The Keynesian school of economics advocates something that is contrary to the theory of capitalism, namely the interference of the public sector in improving the economy. The theory of capitalism opposes the interference of the role of government and the public sector in the economy. The capitalists believe that an uninterrupted market will achieve its own equilibrium. Keynes' theory criticizes government for increasing savings but not encouraging consumption. Keynes also supports controlled distribution of wealth when needed. Keynes' theory then concludes that for the distribution of wealth, the poorer people are given a certain amount of money, they will spend it rather than save it; which then drives economic growth[19].

\subsubsection{Neokeynes Theory}

In Neokeynes theory, the most important component is about investment capital, namely in the process of determining the success of economic growth.

\subsection{Foreign iDirect investment (FDI)}

Krugman and Obstfeid defines FDI is the flow of fund enter (capital inflow) to one Country, is like foreign company which opens a branch of its company to another country, should do it specific ownership, specific location, internalization. having various kinds of alternatives to enter foreign markets [20].

\section{Data and Econometric Models}

\subsection{Population, Sample and Sampling}

Population is the data of monetary variables of Indonesia and Malaysia, while the sample is part of the population, the idata of monetary variables of Indonesia and Malaysia during the period 40 of the last years 1980 to 2019. The sampling technique or sampling is nonprobability sampling with quota sampling types.

\subsection{Research operational variables}

To facilitate the research, the research variables need to be defined both conceptually and operationally and given a measurement scale. The definitions of the variables in the research are as follows:

\begin{tabular}{|c|c|c|c|}
\hline No & Variable Name & Operational Definition & Measuremant Scale \\
\hline 1 & Total money supply & $\begin{array}{l}\text { Total money supply consists of currency, } \\
\text { demand deposits, quasi-money, securities } \\
\text { other than shares up to } 1 \text { year remaining }\end{array}$ & Nominal in USD \\
\hline 2 & Interest Rate & Lending rate - Deposit rate & Ratio in \% (Percent) \\
\hline 3 & Inflation & Inflation proxied by GDP deflator & Ratio in percent $(\%)$ \\
\hline 4 & Public savings & Total public savings in commercial banks & Nominal in USD \\
\hline 5 & Exchange Rates & Comparative Exchange Rates 1 USD with & Nominal in IDR and \\
\hline
\end{tabular}




\begin{tabular}{|c|c|c|c|}
\hline No & Variable Name & Operational Definition & Measuremant Scale \\
\hline & & IDR and RM currency & RM currency units \\
\hline 6 & Economic Growth & $\begin{array}{l}\text { Economic growth is proxied by the GDP } \\
\text { growth rate, with the formula: } \\
\text { GDPt - GDPt-1 }\end{array}$ & Ratio in percent \\
\hline & & PE $=$------------------ & \\
\hline 7 & $\begin{array}{l}\text { Foreign Direct } \\
\text { Investment (FDI) }\end{array}$ & $\begin{array}{l}\text { Net FDI is the capital inflow to a country } \\
- \text { the outflow of funds from a country }\end{array}$ & Nominal in USD \\
\hline
\end{tabular}

\subsection{Data analysis technique}

The data analysis techniques used in this research are as follows:

\subsubsection{Quantitative Analysis}

The steps of the quantitative analysis carried out are:

a. Data input. The multiple linear regression equation model is shown in formula (1).

$$
\begin{aligned}
& \mathrm{Y}=\alpha+\beta 1 \mathrm{X} 1+\beta 2 \mathrm{X} 2+\beta 3 \mathrm{X} 3+\beta 4 \mathrm{X} 4+\beta 5 \mathrm{X} 5 \\
& \mathrm{Z}=\alpha+\beta 1 \mathrm{X} 1+\beta 2 \mathrm{X} 2+\beta 3 \mathrm{X} 3+\beta 4 \mathrm{X} 4+\beta 5 \mathrm{X} 5+\beta 6 \mathrm{Y}
\end{aligned}
$$

b. Then the second equation is changed to be like in formula (2).

$\mathrm{Y}=\alpha+\beta 1 \ln \mathrm{X} 1+\beta 2 \ln \mathrm{X} 2+\beta 3 \ln \mathrm{X} 3+\beta 4 \ln \mathrm{X} 4+\beta 5 \ln \mathrm{X} 5$,

$\mathrm{Z}=\alpha+\beta 1 \ln \mathrm{X} 1+\beta 2 \ln \mathrm{X} 2+\beta 3 \ln \mathrm{X} 3+\beta 4 \ln \mathrm{X} 4+\beta 5 \ln \mathrm{X} 5+\beta 6 \ln \mathrm{Y}$

Where:

$\mathrm{Z}=$ dependent variable $=$ foreign direct investment

$\mathrm{Y}=$ dependent variable $=$ economic growth

$\mathrm{A}=\mathrm{constant}$

$\mathrm{X} 1=$ independent variable $1=$ sum of money in circulation

$\mathrm{X} 2=$ independent variable $2=$ interest rate

$\mathrm{X} 3=$ independent variable $3=$ inflation

$\mathrm{X} 4=$ independent variable $4=$ saving

$\mathrm{X} 5=$ independent variable $5=$ exchange rate

\subsubsection{Classic Assumption Test}

Classic Assumption Test in linear regression with data time series test assume classic that needs to be done:

a. Normality Test. A good regression model, the residual data is normally distributed, with a p-value $<0.05$ or a Jarque-Bera value $>2$ (Ghozali, 2016)

b. To test if there is a strong connection between the independent variables, use the Multicollinearity Test. The VIF multicollinearity test was employed as the tool. If it is greater than 10 , this test value is good.

c. Heteroscedasticity test to see if there is a difference in residual variance from one observation to the next in the regression model. With a p-value $>0.05$, a good regression model shows no signs of heteroscedasticity. 
d. Heteroscedasticity test to see if there is a difference in residual variance from one observation to the next in the regression model. With a p-value $>0.05$, a good regression model shows no signs of heteroscedasticity a period $t$ and the previous period. Autocorrelation can be known by the Breusch-Godfrey Test. If the prob score $>0.05$ then there is no autocorrelation.

\subsubsection{Feasibility Test Model Regression}

a. F-statistics test. The F-statistical test determines if all of the model's independent variables are equal an overall or joint effect on the independent variable (Kuncoro, 2012). This test was carried out with a confidence level of $15 \%$. This test is carried out in two ways, namely:

1. If the value of F statistic $>0.05, \mathrm{H} 0$ is accepted or $\mathrm{H} 1$ is rejected, If the value of Fstatistic $<.05$. H0 is rejected or $\mathrm{H} 1$ is accepted.

2. $\mathrm{H} 0$ is rejected or $\mathrm{H} 1$ is approved if the F-statistic value is greater than Ftabel. H0 is accepted or $\mathrm{H} 1$ is denied depending on the value of $\mathrm{F}$ statistic. Ftable.

3. H0 is rejected, which means that all independent variables $\mathrm{i}$ as a whole affect the independent variables.

b. Test t-statistics. This a test was run to see how the independent variables affected the dependent variable on an individual basis. To learn more the significance of the effect, criterion is used: $t$-counts $>\mathrm{t}$-table means has an effect.

c. Determination Coefficient (R2). The coefficient of determination measures how well the independent and dependent variables work together to explain the dependent variable's change the value of $\mathrm{R} 2$ ranges from 0 to $1(0 \leq \mathrm{R} 2 \leq 1)$.

\section{Results and Discussion}

\subsection{Indonesia}

\subsubsection{Multiple Linear Regression of Economic Growth}

\subsubsection{Classical assumption test}

Based on the findings of research and the analysis of data obtained the following things:

a. The In the normalcy test, Jarquqe-Bera has a value of 4.50. This value exceeds 2, indicating that the data is regularly distributed.

b. The value of the Chi-Square Prob in the LM Test Breusch + Godfrey correlation test is 0.6799 . This value is greater than 0.05 which means that There is no association between the two symptom in the research model

c. The value of the Chi-Square Prob of Test White's heteroscedasticity test is 0.0628 . This value is greater than 0.05 which means that there are no symptoms of heteroscedasticity in the research model

d. The VIF Multicollinearity Test provides the following values:

e. The money supply has a value of 80,74181 which is greater than 10 . This shows that there is no multicollinearity problem in the money supply

f. The interest rate VIF value is 1.318758 , which is less than 10. At the interest rate there is a correlation with economic growth. 
g. The VIF value for inflation is 1.432381 which is smaller than 10 . This means that inflation has a correlation with economic growth

$\mathrm{h}$. The VIF value for public saving is 18.11603 which is greater than 10 . Public saving has no correlation with economic growth

i. The value of the VIF exchange rate or currency value of 36.16817 is greater than 10 . The exchange rate has no correlation with economic growth Multiple Linear Regression Equation

$\mathrm{Y}=26.82+0.98 \mathrm{X} 1-0.24 \mathrm{X} 2-0.19 \mathrm{X} 3-0.20 \mathrm{X} 4-3.47 \mathrm{X} 5$

Multiple linear regression equation contains the meaning:

a. If the value Money supply, interest rate, inflation, and public savings are all factors to consider and the exchange rate is equal to 0 units, then economic growth is $26.82 \%$

b. If the money supply increases/decreases by 1 unit, Then, by 0.98 units, economic growth increases or declines.

c. If the interest rate increases/decreases by 1 unit, Then, by 0.24 units, economic growth decreases/increases.

d. If inflation increases/decreases by 1 unit, then economic growth decreases/increases by 0.19 units

e. If public saving increases/decreases by 1 unit, then economic growth decreases/increases by 0.20 units

f. If the exchange rate increases/decreases by 1 unit, then economic growth decreases by 3.47 units.

1. F-statistic test. Taken together, the money supply, Economic growth is influenced by interest rates, inflation, public savings, and the currency rate. This is indicated by the Prob value (F-statistic) of 0.000000 which is smaller than 0.05 .

2. t-statistic test. Individually, the relationship and The following are the effects of independent factors on the dependent variable:

a. The money supply is There is a positive relationship between the two and no effect on economic growth.

b. Interest rates are negatively They are intertwined and have a major impact on economic progress.

c. Inflation is negatively related and has a significant effect on economic growth.

d. Public saving is negatively related and has no impact on the economy

e. Exchange rate or exchange rate is negatively It is tied to economic growth and has a substantial impact on it.

3. The contribution of the money supply, interest rate, inflation, public saving and exchange rate to economic growth is $95.76 \%$ Other factors not included in the study influence the remaining 4.24 percent.

\subsubsection{FDI Multiple Linear Regression}

\subsubsection{Classical Assumption Test}

Based on the findings of research and the analysis of data obtained the following things:

a. The Jarquqe-Bera value in the normality test is 6.26 This value is greater than 2 , which means the The data is generally disperse. 
b. On the LM Test Breusch + Godfrey correlation test, the Chi-Square Prob value is 0.2657. This score is greater than 0.05 , indicating that the study model does not have an auto correlation symptom.

c. The value of the Chi-Square Prob of Test White's heteroscedasticity test is 0.2150 . This value is greater than 0.05 which means that there are no symptoms of heteroscedasticity in the research model

d. The VIF Multicollinearity Test provides the following values:

e. Economic growth value of VIF 23.56412 is greater than 10. This means that in economic growth there is no multicollinearity problem

f. The money supply has a value of 85.74098 which is greater than 10 . This shows that there is no multicollinearity problem in the money supply.

g. The interest rate of VIF value is 5.442378 which is less than 10 . At the interest rate there is a correlation with FDI

h. The VIF value for inflation is 12.38984 , which is greater than 10 . This means that inflation does not have a collinearity problem

i. The value of VIF for public saving is 18,19719 which is greater than 10. Public saving has no correlation with economic growth

j. The value of the VIF exchange rate or currency value is 52.09317 which is greater than 10 . The exchange rate has no correlation with economic growth

\subsubsection{The Multiple Linear Regression Equation For FDI}

$\mathrm{Z}=2.35+1.37 \mathrm{X} 1-0.08 \mathrm{X} 2-0.01 \mathrm{X} 3+0.37 \mathrm{X} 4-2.30 \mathrm{X} 5-0.08 \mathrm{Y}$

The multiple linear regression equation contains the following meanings:

a. If the value of the money supply, interest rate, inflation, public saving, exchange rate and economic growth is equal to 0 units, then FDI is 2.35 units $\backslash$

b. If the money supply increases/decreases by 1 unit, then FDI rises or falls by 1.37 units.

c. If the interest rate increases/decreases by 1 unit, then FDI decreases/increases by 0.08 units

d. If inflation increases/decreases by 1 unit, Then, by 0.01 units, FDI decreases/increases.

e. If public saving increases/decreases by 1 unit, then FDI rises or falls by 0.37 units.

f. If the exchange rate increases/decreases by 1 unit, then economic growth decreases by 2.30 units.

1. F-statistic test. Taken together, the money supply, interest rates, inflation, public savings, exchange rates and economic growth have a significant effect on FDI. This is indicated by the Prob value (F-statistic) of 0.000000 which is smaller than 0.05 .

2. Individually the relationship and The impacts of independent factors on the dependent variable are as follows::

a. The money supply is positively related and has no effect on FDI

b. .Interest rates are negatively related and have no effect on FDI

c. Inflation is negatively related and has no effect on FDI

d. Public saving is positively related and has no effect on FDI

e. The exchange rate or exchange rate is negatively related and has a big impact on foreign direct investment

f. .Economic growth is negatively related and has no effect on FDI:

3. The contribution of the money supply, interest rate, inflation, public saving and exchange rate to economic growth is $81.38 \%$ and the remaining $18.62 \%$ is influenced by other factors not included in the study. 


\subsection{Malaysia}

\subsubsection{Multiple Linear Regression of Economic Growth}

\subsubsection{Classical Assumption Test}

Based on the findings of research and the analysis of data obtained the following things:

a. The Jarquqe-value Bera's in the normalcy test is 4.45 . This value exceeds 2 , indicating that the data is regularly distributed.

b. In the LM Test Breusch + Godfrey correlation test, the Chi-Square Prob has a value of 0.9424 . This score is greater than 0.05 , indicating that the study model does not have an auto correlation symptom.

c. The value of the Chi-Square Prob of Test White's heteroscedasticity test is 0.0257 . This value is smaller than 0.05 which means there are symptoms of heteroscedasticity in the research model

d. The VIF Multicollinearity Test provides the following values:

e. The money supply has a value of 56.04747 which is greater than 10 . This shows that there is no multicollinearity problem in the money supply.

f. The interest rate VIF value is 15.87559 , which is greater than 10 . At the interest rate there is no correlation with economic growth.

g. The VIF value for inflation is 11.54731 which is greater than 10 . This means that inflation has no correlation with economic growth

h. The value of VIF for public saving is 43,03966 which is greater than 10. Public saving has no correlation with economic growth

i. The value of the VIF exchange rate or currency value of 4.749199 is smaller than 10 . The exchange rate has a correlation with economic growth

Multiple linear regression equation $\mathrm{Y}=39.36-4.51 \mathrm{X} 1-1.22 \mathrm{X} 2-1.10 \mathrm{X} 3+3.08 \mathrm{X} 4-7.33 \mathrm{X} 5$

The multiple linear regression equation contains the following meanings:

a. If the value of the money supply, interest rate, inflation, public saving and the exchange rate is equal to 0 units, then economic growth is $39.36 \%$

b. If the money supply increases/decreases by 1 unit, then economic growth decreases/increases by 4.51 units.

c. If the interest rate increases/decreases by 1 unit, Then, by 1.22 units, economic growth decreases/increases.

d. If inflation increases/decreases by 1 unit, Then, by 1.10 units, economic growth decreases/increases.

e. If people's savings increase/decrease by 1 unit, then economic growth will increase/decrease by 3.08 units

f. If the exchange rate increases/decreases by 1 unit, then economic growth decreases by 7.33 units.

1. F-statistic test. Taken together, the money supply, Economic growth is influenced by interest rates, inflation, public savings, and the currency rate. The Prob (F-statistic) value of 0.000340 , which is less than one, indicates this. 0.05 .

2. t-statistic test. Individually, the relationship The following are the effects of independent factors on the dependent variable:

a. The money supply is negatively related and has no economic ramifications. 
b. Interest rates are negatively related and have a significant effect on economic growth

c. Inflation is There is a negative relationship between the two, and it has a substantial impact on economic growth.

d. Public saving is favorably related to economic growth and has no effect on it.

e. Exchange rate or exchange rate is negatively It is unrelated to economic growth and has no impact on it.

3. The contribution of the money supply, interest rate, inflation, public saving and exchange rate to economic growth is $48.74 \%$ and the remaining $51.26 \%$ is influenced by other factors not included in the study.

\subsubsection{FDI Multiple Linear Regression}

\subsubsection{Classical Assumption Test}

It is unrelated to economic growth and has no impact on it obtained the following things:

a. The Jarquqe-Bera value in the normality test is 37.26 This value is greater than 2 , which means the The data is generally dispersed.

b. The value of the Chi-Square Prob on the Breusch+Godfrey LM Test correlation test is 0.0853 . This value is greater than 0.05 which means With the research model, there is no autocorrelation symptom

c. The value of the Chi-Square Prob of Test White's heteroscedasticity test is 0.0772 . This value is greater than 0.05 which means that there are no symptoms of heteroscedasticity in the research model

d. The VIF Multicollinearity Test provides the following values:

e. Economic growth value of VIF 1.95-1997 is smaller than 10. This means that in economic growth there is a problem of multicollinearity

f. The money supply has a value of 60.36156 which is greater than 10 . This demonstrates that there is no concern with multicollinearity in the money supply.

g. The interest rate value of VIF is 21.42094 which is greater than 10. At the interest rate there is no correlation with FDI.

h. The VIF value for inflation is 14,21809 , which is greater than 10 . This means that inflation has no collinearity problem.

i. The value of VIF for public saving is 44,34771 which is greater than 10 . Public saving has no correlation with economic growth

j. The value of the VIF exchange rate or currency value of 5.118868 is smaller than 10 . The exchange rate has a correlation with economic growth

The multiple linear regression equation for FDI

$\mathrm{Z}=-6.64-0.07 \mathrm{X} 1+0.20 \mathrm{X} 2+0.24 \mathrm{X} 3+1.34 \mathrm{X} 4+0.87 \mathrm{X} 5+0.15 \mathrm{Y}$.

The multiple linear regression equation contains the following meanings:

a. If the value of the money supply, interest rate, inflation, public saving, exchange rate and economic growth is equal to 0 units, then FDI is -6.64 units

b. If the money supply increases/decreases by 1 unit, then FDI decreases/increases by 0.07 units

c. If the interest rate FDI/increases/decreases by 0.20 units for every 1 unit increase/decrease.

d. If inflation increases/decreases by 1 unit, then FDI 0.24 units increases/decreases

e. If public saving increases/decreases by 1 unit, then FDI 1.34 units increases/decreases 
f. If the exchange rate increases/decreases by 1 unit, then economic growth 1.34 units increases/decreases

1. Taken together, the money supply, Interest rates, inflation, public savings, currency exchange rates, and economic development all influence FDI. The Prob value (Fstatistic) of 0.000000 , which is less than 0.05 , indicates this.

2. Individually the relationship and The following are the effects of independent factors on the dependent variable:

a. The money supply is negatively related and has no effect on FDI

b. Interest rates are positively related and have no effect on FDI

c. Inflation is positively related and has a significant effect on FDI

d. Public saving is positively related and has no effect on FDI.

e. Exchange rate or exchange rate is related in a favorable way and has no influence on FDI

f. Economic Growth is correlated with and has a significant impact on FDI:

3. Test of determination. The contribution of the money supply, interest rate, inflation, public savings and the exchange rate to economic growth is $69.68 \%$ Other factors not included in the study influence the remaining 30.32 percent.

\section{Conclusions and Recommendation}

\subsection{Conclusion}

Based on the findings of the study, it is obtained that several conclusions can be drawn, namely:

a. Indonesia

1. In Indonesia, together the amount of money in circulation, interest rates, inflation, savings, and exchange rates have a significant effect on growth of the economic. This is indicated by value prob (F-statistics) is equal to i0,000000

2. In Indonesia, together with the amount of money in circulation, interest rates, inflation, savings, exchange rates/exchange rates idsn Foreign Direct Investment (FDI) is influenced by economic growth. expansion of the economy. This is indicated with an iprob value of (F-statistics) of 0.000000

3. The amount of money in circulation is positively related and has no significant effect either on economic growth or Foreign Direct Investment

4. Interest is inversely proportional to either economic growth or foreign direct investment. Interest has a large impact on economic growth, but it has no positive impact on inflation Foreign Direct Investment.

5. Inflation is negatively related to both economic growth and Foreign Direct Investment. Inflation has a significant effect on economic growth, but has no significant effect on Foreign Direct Investment

6. Savings is negatively related to economic growth and positively related to Foreign Direct Investment. Savings neither have a big impact on economic growth or Foreign Direct Investment/

7. The exchange rate has a positive and negative relationship and Both economic development and foreign direct investment are affected significantly.

8. Economic growth is negatively related and has no Foreign Direct Investment has a huge impact. 
b. Malaysia

1. In Malaysia, the sum of money in circulation, Economic growth is influenced by interest rates, inflation, savings, and currency rates. The importance of demonstrates this prob (F-statistic) is 0.000340

2. In Malaysia, the sum of money circulation, Foreign Direct Investment is influenced by interest rates, inflation, savings, exchange rates, currency rates, and economic growth. This is shown by the value of prob (F-statistic is 0,000000

3. The amount of money in circulation is negatively related and has no either has a considerable impact on economic growth or on Foreign Direct Investment

4. Interest is negatively It is tied to economic growth and has a substantial impact on it. Interest, on the other hand, is positively associated in this way and has no effect. on Foreign Direct Investment.

5. Inflation has a significant impact on economic growth and is positively related to it. It is, nonetheless, linked and has a significant impact on Foreign Direct Investment.

6. Savings It has a favorable association and has no major impact on economic growth or on Foreign Direct Investment.

7. The exchange rate is negatively It is unrelated to economic growth and has no effect on it. It does, however, have a favorable association and has no discernible effect on Foreign Direct Investment.

8. Economic growth is positively related to Foreign Policy and has a major impact on its Direct Investment.

\subsection{Recommendation}

Based on the conclusions based on the results of the research, the authors suggest several things as follows:

a. Central Bank is more open in setting the monetary policy, so that the public has asymmetric information, so that they act according to the expectations of Bank Central

b. Of the five monetary variables, total money in circulation, interest rates, inflation, savings and exchange rates. Bank Sentral can only set interest rates. The determination of the interest rate should be at a moderate level, in the sense that it is neither too low nor too high. The determination of the interest rate will have implications.

c. If the interest rate falls, the community will borrow more, so the amount of money in circulation increases and vice versa. A large amount of circulating money can be used for community consumption icon and investment so that economic growth will increase

d. A lower interest rate will also reduce inflation. Bank Sentral generally have a low inflation target

e. The interest rate is low, the community doesn't want to save, so that causes the savings for the community to be low

f. A high interest rate will encourage the inflow of foreign capital, so that it will increase the foreign currency in the country, as a result, the local currency will strengthen

g. A high rate of interest will encourage the FDIC (Foreign Direct Investment) is a term used to describe the inflow of foreign direct investment. 


\section{References}

[1] Aroef, Mathias, Jusman Syafii Djamal, Hatim Ilwan, 2009. Grand Techno- Economic Strategy. Jakarta, PT Mizan Publika

[2] Barro, Robert J. Angus C Chu, Guido Cozzi. 2017. Intermediate Macroeconomics. Boston, Massachusetts, USA. Cengage Learning

[3] Keith C, Brown and Frank K Reilly. 2009. Analysis of Investments and Managementof Portofolios. 9th Edition.Canada: South western Cengage Learning

[4] Case, Karl E., Ray C Fair.,. Sharon M oster. 2017. Priciples of Economics. 12th Edition. London. Pearson Education Limited

[5] Cassel, Karl Gustav. 2016. The nature and Necessity of Interest. Edisi Cetak Ulang. Marrickville, New South Wales, Australia. Wentworth Press.

[6] Natsir, M. 2014. Ekonomi Moneter dan Kebanksentralan. Jakarta. Penerbit Mitra Wacana media

[7] Warjiyo, Perry. Solikin M Juhro. 2014. Kebijakan bank Sentral. Jakarta. Rajawali Press

[8] Schwartz, Anna J. 20121. Money Supply. National Bureau of Economic Research. Praha. Library of economics and Liberty.

[9] Pindyck, Robert., Daniel L Rubinfeld.2007. Mikroekonomi. Edisi keenam. Jakarta. Penerbit Indeks

[10] Samuelson, A., Paul Nordhaus., D. William. 2004. Ilmu Makroekonomi, Edisi 17. Jakarta. PT Media Global Edukasi

[11] Mishkin, Frederick S. 2008. Ekonomi Uang, Perbankan dan Pasar Keuangan. Jakarta. Salemba empat

[12] Todaro, Michael P dan Stephen C Smith. 2011. Pembangunan Ekonomi, Edisi kesebelas, Jakarta. Penerbit Erlangga

[13] Rapanna, Patta, Zulfikry Sukarno. 2017. Ekonomi Pembangunan. Makasar. CV Sah Media

[14] Nov, Deliar. 2018. Perkembangan Pemikiran Ekonomi. Jakarta. Raja Grafindo persada

[15] Jhingan, M.L. 2018. Ekonomi Pembangunan dan Perencanaan. Cetakan 18. Jakarta. Raja Grafindo Persada

[16] Skousen, Mark. 2016. Sejarah Pemikiran Ekonomi, sang Maestro, Teori-Teori Ekonomi Modern. Penerjemah Tri Wibowo BS. Jakarta. Prenada Group.

[17] Smith, John Adam. 1977. An Inquiry into the Nature and Causes of the Wealth of nations. Edisi Cetak Ulang Chicago, USA. Chicago University Press.

[18] Schumpeter, Joseph A. 2017. The Theory of economic Development. Edisi Cetak Ulang. London. Penerbit Routledge

[19] Keynes, John Maynard. 2016. The General theory of Employment, Interest, and Money. Edisi Cetak Ulang. New York. Stellar Classics

[20] Krugman, Paul R. Maurice Obstfeld dan Marc Melitz. 2018. International Economics, Theory and Policy. Eleven Edition. London, Newyork. Pearson

[21] Rostow, W.W. 1991. The Stage of Economic Growth, A Non-Comunist Manifesto. 3th Edition. Cambridge. Cambridge University Press

[22] Harrod, Roy F. 1980. Toward a Dynamic Economics: Some Recent Developments of Economic Theory and Their application to Policy. Edisi Cetak Ulang. Santa Barbara, California, USA. Praeger

[23] Budiono. 1992. Teori Pertumbuhan Ekonomi. Yogyakarta. Badan Penerbit Fakultas Ekonomi UGM. 